\title{
Does the Market Know? Going Concern Opinion Release and Firm Fundamentals
}

\author{
Jian Huang \\ Department of Finance, College of Business and Economics \\ Towson University, Towson, MD 21252, US \\ Han $\mathrm{Yu}$ (Corresponding author) \\ Department of Economics and Finance, School of Business \\ Southern Connecticut State University \\ New Haven, CT 06515, US \\ Tel: 1-203-392-5628_E-mail: yuh5@ southernct.edu
}

Received: September 19, 2018 Accepted: January 9, 2019 Published: January 22, 2019

doi:10.5296/ijafr.v9i1.13673

URL: https://doi.org/10.5296/ijafr.v9i1.13673

\begin{abstract}
Using a significant auditing event-the going concern audit opinion-we investigate the market's forecasting ability and the importance of firm fundamentals in predicting the going concern event. First, we find that the equity market signals the upcoming going concern announcement as early as 30 days in advance. Specifically, during the window of [-30, -1] leading up to the announcement, the excess returns to going concern firms are $9.98 \%$ worse than the matched distressed firms. Moreover, short sellers, a group of sophisticated investors, significantly increase their shorting activities during days before the release of the going concern opinions. Furthermore, we find that firm fundamentals, which are observable to the market, are significantly predictive to the issuances of going concern. These variables include a firm's operating performance (return on assets and operating cash flows), equity market liquidity, stock momentum, and filing delay. Overall, our evidence supports the perception that the market can forecast the going concern opinion release and points out its possible channel as well.
\end{abstract}

Keywords: Going concern audit opinion release, Market prediction, Firm fundamentals JEL Codes: G12, G14, M42 


\section{Introduction and Background}

The going concern opinion serves as a formal warning to investors from an independent third party. When the doubt about the entity's survival as a going concern in the nearest twelve months becomes substantial, the auditor issues a going concern opinion in the auditor report that is submitted to the SEC. The audit opinion normally contains the going concern judgment and the reasons why such a judgment is issued. The matrix used by all auditors regarding the evaluation criterion includes business operation conditions, the management plans, current and prior financial statements, and other insider information. The going concern opinion, especially the first-time going concern, contains valuable information to the market and market participants (Chen and Church, 1996; Holder-Webb and Wilkins, 2000; Hopwood et al., 1989; Menon and Williams, 2010; and Huang, Yu, and Zhang, 2019).

Studies have focused on how the market reacts to the opinion following going concern news releases. Fleak and Wilson (1994) and Jones (1996) report a significant negative market return for going concern opinions. A more recent study by Menon and Williams (2010) investigates short-term market reaction to first-time going concern opinions and find a significant negative reaction, with a cumulative three-day excess return of $-6.28 \%$. Kausar, Taffler, and Tan (2009) examine the long-term market reaction to going concern opinions and find that the market underreacts to the announcements and produces a $-14 \%$ downward drift during the subsequent twelve months. Similarly, Kausar, Taffler, and Lu (2004) provide similar results in the U.K. markets.

As going concern opinions represent a significant negative event with adverse market reactions, it is an issue whether the market as a whole can predict this event and distinguish the going concern firms from the rest of the distressed firms without such an audit opinion. Most of the going concern opinions are submitted along with $10-\mathrm{K}$ reports in the audit report section (Note 1).

Technically, an audit report contains confidential information that should not be disclosed before the filing date unless the management team chooses to announce critical information to the public earlier. Thus, the filing date for the company to submit their SEC filings commonly becomes the first public awareness of the information contained in the audit report, in which, a going concern opinion may or may not be present. We document that the equity market can detect the going concern opinion announcements, and during the window of [-30, -1] leading up to the announcement, the excess returns to going concern firms are $9.98 \%$ worse than the matched distressed firms.

This leads us to the next question about how the market becomes aware of this confidential event. On the one hand, the going concern opinion is closely related to the financially distressed condition and the probability of failure; studies have addressed the possible link between the prediction of going concern opinion and the publicly available information contained in accounting reports. For example, Mutchler (1985) studies the going concern decision making by using a multivariate analysis. DeFond et al. (2002) find that firms with low liquidity/operating cash flows and low profitability have a high likelihood of a future 
going concern. Thus, the use of material information contained in accounting reports provides us with a way to identify going concern firms.

On the other hand, going concern opinions are significantly negative news released to the public. Prior research focuses on the value relevance of going concern opinions and finds the post-announcement market reactions are significantly negative. Given the fact that going concern opinions provide a great investment opportunity to investors, it is reasonable for us to suspect whether we can identify future going concern issuances using market expectation before the news release. It is well addressed that some investor groups, especially sophisticated investors, use the readily available information to predict and identify financially distressed or underperformed companies (Field and Lowry, 2009; Al Haddidi and Abu Mousa, 2016; Anderson and Huang, 2017; Anderson, Huang, and Torna, 2017; Kim, Lee, and $\mathrm{Na}, 2019$ ).

In this study, we use both the accounting and stock market indicators and investigate their roles of giving an early alert of possible going concern opinion issuances. Our main hypothesis is that both the material accounting information and market trading indicators help differentiate going concern firms before the announcement release. We also examine the possible channel of going concern recognition. D'Avolio (2002) point out that low-priced stocks are less attractive to institutional investors due to the high borrowing cost associated with equity lending. Prior research (Kausar, Taffler, and Tan, 2008; Menon and Williams, 2010) points out that going concern firms present price drift after the announcement, and it is due to the lack of involvement by sophisticated or institutional investors targeting such news. We use proxies to measure trading patterns of both general investors and a group of sophisticated investors (short sellers) and examine whether sophisticated investors are interested in the going concern investment opportunity and how their involvements help to predict upcoming going concern announcements.

We find that both the financial performance measures and the market indicators have predictive powers of the upcoming going concern opinions. Compared to a matched sample of distressed companies but without going concern opinions, our going concern sample is associated with low or negative profitability, low operating cash flows, decreased equity liquidity, and longer filing delay. Moreover, going concern firms present significantly negative six months return momentum prior to the news release. Furthermore, although most going concern companies are traded at depressed price levels, short sellers are quite attracted to the event and shorting activities increase significantly prior to the going concern announcements. Thus, this study contributes to the understanding of the investment value of going concern announcements, which is shown in the market measure of both ordinary investors (momentum) and sophisticated investors (short selling volume). It also points out that the market and especially sophisticated investors (short sellers) are likely to predict upcoming negative corporate news based on both the material information contained in financial reports and market indicators (Jiang and Pang, 2016; Meng, Li, Jiang and Chan, 2017; Cheung, Hung, Lam, and Leung, 2018.) 


\section{Mll Macrothink}

International Journal of Accounting and Financial Reporting

ISSN 2162-3082

2019, Vol. 9, No. 1

The next section describes our sample and methodology in examining the market's ability in predicting the going concern opinion release and possible channels. Section 3 presents empirical results, and section 4 concludes the paper.

\section{Data and Methodology}

\subsection{Sample}

We select only first-time going concern opinions that appear in 10-K filings of public traded companies from Audit Analytics from 2005 to 2010 because subsequent opinions do not provide much new information to investors (Kausar, Taffler, and Tan, 2009; Menon and Williams, 2010; Mutchler et al. 1997). We require firms to have necessary financial variables in the Compustat database, stock trading information in CRSP, and short selling volume information from the SHO database. We exclude companies that file bankruptcy within one year before the first-time going concern report, and we delete companies in the financial industry with SIC code in the 6000s. After the screening, we are left with 272 going concern audit opinions. To compare the market perception of going concern firms versus non-going concern firms, we create a matched sample with the similar firm condition but without going concern audit reports in their 10-Ks. As found in Reynolds and Francis (2000), financially distressed firms usually report either negative earnings or operating cash flows during the current fiscal year. Thus, the matched firms are selected with similar financially distressed conditions as the treatment group. Specifically, we follow DeFond et al. (2002) in choosing the three most similar companies for each going concern opinion in size, stock trading price, profitability, and whether they have the same signs of operating cash flow and net income. To control for the industry and time fixed effect, we also require the matched firms to be in the same industry (three-digit SIC code) and have the same fiscal year auditor's opinions. We delete the duplicate company-year observation in the matching process, and our final sample yields a 233 first time going concern opinions with 552 matched firms.

\subsection{Methodology}

We test the market's signaling ability by estimating the following probit model of going concern probability.

$$
\begin{aligned}
\text { Going Concern } & =\beta_{0}+\beta_{1}(\text { EXRET })+\beta_{2}(\log (\text { Market Size }))+\beta_{3}(\text { Momentum }) \\
& +\beta_{4}(\mathrm{M} / \mathrm{B})+\beta_{5}(\text { Price })+\beta_{6}(\text { EXRET })+\beta_{7}(\text { Total Assets })+\beta_{8}(\text { ROA }) \\
& +\beta_{9}(\text { Leverage })+\beta_{10}(\text { Corp.Liquidity })+\beta_{11}(\text { Loss }) \\
& +\beta_{12}(\text { OP Cash Flow })+\beta_{13}(\text { Report Lag })+\beta_{14}(\text { Big } 4)
\end{aligned}
$$

The dependent variable is an indicator equaling one for firms with a first-time going concern opinion, and 0 for the matched sample. Independent variables include a group of fundamental firm-level financial variables and a group of market-signaling variables to present the informational environment prior to the release of going concern audit reports. Table I presents the detailed variable descriptions. 
We focus on major equity trading indicators to test whether the market can identify the upcoming going concern events. We include measures of pre-announcement short-term returns, trading prices, the market size, market-to-book value, and momentum. We also include the abnormal short selling volume to measure the trading pattern of short sellers, a group of sophisticated investors. Prior research shows that short selling activity could potentially discipline accounting reporting and help the corporate information diffusion (Massa, Zhang, and Zhang, 2015; Fang, Huang and Karpoff, 2016). Specifically, pre-announcement short-term returns are cumulative returns in excess of the market returns during the $(-5,-1)$ days before the release of the going concern audit report in the $10-\mathrm{K}$. It measures the short-term market predictability prior to the event. Stock trading prices, market size, and market-to-book value are measured based on equity value 90 days before the going concern event.

Table 1. Variable definition

\begin{tabular}{|c|c|c|}
\hline Variable & Definition & Source \\
\hline Going Concern $_{t}$ & $\begin{array}{l}\text { A dummy which equals } 1 \text { if the company receives } \\
\text { first-time going concern opinion in the audit report, and } \\
0 \text { otherwise. }\end{array}$ & AuditAnalytics \\
\hline $\operatorname{EXRET}_{(-\mathrm{n},-\mathrm{m})}$ & $\begin{array}{l}\text { Buy-and-hold excess returns during }(-n,-m) \text { days prior } \\
\text { to audit report release using CRSP value-weighted } \\
\text { benchmark. }\end{array}$ & CRSP \\
\hline Momentum $_{\mathrm{t}}$ & $\begin{array}{l}\text { Compounded returns during }(-150,-30) \text { days prior to } \\
\text { audit report release date. }\end{array}$ & CRSP \\
\hline $\begin{array}{l}\text { Log(Market } \\
\text { Size })_{t}\end{array}$ & $\begin{array}{l}\text { Share price } \times \text { total shares outstanding } 30 \text { days prior to } \\
\text { audit report release date, } \log \text { adjusted. }\end{array}$ & CRSP \\
\hline $\mathrm{M} / \mathrm{B}_{\mathrm{t}-1}$ & $\begin{array}{lccc}\text { (Fiscal year-end } \quad \text { pricex } & \text { total shares } \\
\text { outstanding)/Common equity value. } & & \end{array}$ & Compustat \\
\hline $\mathrm{ROA}_{\mathrm{t}-1}$ & $\begin{array}{l}\text { Net income / total asset in the fiscal year of the audit } \\
\text { report being analyzed. }\end{array}$ & Compustat \\
\hline $\begin{array}{l}\text { Year-End } \\
\text { Price }_{\mathrm{t}-1}\end{array}$ & Fiscal year-end share price. & Compustat \\
\hline $\operatorname{ABSSR}_{(-5,-1)}$ & $\begin{array}{l}\text { Average daily abnormal short selling during }(-5,-1) \\
\text { days prior to audit report release. Daily abnormal short } \\
\text { selling = ((shorting volume / shares outstanding) - } \\
\text { (average shorting volume / shares outstanding)) / } \\
\text { (average shorting volume / shares outstanding). (average } \\
\text { shorting volume / shares outstanding) is the average } \\
\text { benchmark taken during }(-150,-30) \text { days before audit }\end{array}$ & SHO database \\
\hline
\end{tabular}


report release date.

Operating Cash Operating cash flow/ total asset in the fiscal year of the Compustat Flow $_{\mathrm{t}-1} \quad$ audit report being analyzed.

Leverage $_{t-1} \quad$ Total liability/total assets asset in the fiscal year of the Compustat audit report being analyzed.

Corporate Total current assets/total current liabilities. Compustat

Liquidity $_{\mathrm{t}-1}$

Assets $_{\text {t-1 }}$ (\$Mil) Total assets in the fiscal year of the audit report being Compustat analyzed.

$\operatorname{Loss}_{\mathrm{t}-1}(0 / 1)$

A dummy which equals 1 if the company had negative Compustat net income during year $\mathrm{t}-1$ of audit report year, and 0 otherwise.
Neg. $\quad \mathrm{OCF}_{\mathrm{t}-1}$ A dummy which equals 1 if the company had negative Compustat
$(0 / 1)$ cash flow during year $\mathrm{t}-1$ of audit report year, and 0 otherwise.

\begin{tabular}{llll}
\hline Filing Delay & The gap between filing date and fiscal year-end date. & AuditAnalytics \\
\hline Big & Four & A dummy which equals 1 if the auditor issuing audit & AuditAnalytics \\
Auditort 1 & report is a Big Four auditor, and 0 otherwise. & \\
\hline
\end{tabular}

This table defines all the variables used in this study. Auditor identity and going concern information are from Audit Analytics database. Corporate financial variables are from the Compustat annual database, and stock trading and share information are from the CRSP database. Short selling volume is from SHO database.

The momentum factor captures the six-month excess return (of the market) during the 150 to 31 days before the going concern release in the 10-K filing. Also, we calculate the average daily abnormal short selling ratio immediately prior to the $10-\mathrm{K}$ releases to measure the market's perception of a group of sophisticated investors. The daily abnormal short selling ratio, ABSSR, is the difference between the daily short selling ratio and the average daily short selling ratio, then scaled by the average daily short selling ratio. The average daily short selling ratio is estimated during the $(-150,-31)$ days before the audit report release date.

The choice of financial variables is inspired by DeFond et al. (2002), Reynolds and Francis (2000) and related research to measure the likelihood of financial distress based on corporate fundamentals included in financial reports. In the auditor's opinions section, rationales of issuing a going concern opinion generally fall to the financial distress situation, which includes "low liquidity," "negative earnings and inadequate working capital," "violation of debt covenant," and so forth. For example, firms with negative earnings (Loss = 1) and poor operating cash flows are more likely to fail. High leverage is subject to high borrowing and 


\section{Macrothink}

International Journal of Accounting and Financial Reporting

ISSN 2162-3082 2019, Vol. 9, No. 1

increased interest expenses; thus, the proximity of debt covenant violation is high. Also, we include the corporate liquidity measure since John (1993) reports that the shortage of corporate liquidity leads to financial distress. In addition, we include the total assets of the firm to measure the negotiation power in the event of financial difficulty. Since companies are more likely to avoid failure by renegotiating with their creditors, auditors are less likely to issue going concern opinion to large firms. Reporting lag measures number of days between the fiscal year end and the $10 \mathrm{~K}$ filing date. This is because going concern opinions are associated with longer filing submission intervals (Carcello, Hermanson, and Huss, 1995; Raghunandan and Rama, 1995). The last financial variable included is Big4, which is an indicator of whether the auditor is a member of the Big Four auditing companies.

\section{Empirical Results}

\subsection{Summary Statistics of the Full Sample}

Table 2. Descriptive summary of financial variables

\begin{tabular}{|c|c|c|c|c|c|}
\hline Variables & Mean & Median & Min & Max & Std \\
\hline Going Concern (1/0) & 0.299 & 0 & 0 & 1 & 788 \\
\hline $\operatorname{EXRET}_{(-5,-1)}$ & -0.018 & -0.009 & -0.565 & 0.289 & 0.105 \\
\hline Momentum $_{t}$ & -0.068 & -0.101 & -0.986 & 3.045 & 0.413 \\
\hline Log(Market Size $\left.{ }_{t-1}\right)$ & 18.024 & 18.003 & 15.940 & 22.829 & 1.334 \\
\hline $\mathrm{M} / \mathrm{B}_{\mathrm{t}-1}$ & 2.122 & 1.349 & -4.750 & 19.204 & 3.336 \\
\hline Year-End Price $_{t-1}(\$)$ & 5.409 & 2.890 & 0.055 & 84.300 & 7.854 \\
\hline Abnormal Shorting $(-5,-1)$ & 0.261 & -0.081 & -1.000 & 6.214 & 1.175 \\
\hline $\mathrm{ROA}_{\mathrm{t}-1}$ & -0.208 & -0.099 & -0.752 & 0.301 & 0.250 \\
\hline Operating Cash Flowt-1 & -0.010 & 0.024 & -0.327 & 0.357 & 0.137 \\
\hline Leverage $_{t-1}$ & 0.544 & 0.519 & 0.066 & 1.152 & 0.289 \\
\hline Liquidity $_{\mathrm{t}-1}$ & 2.416 & 1.686 & 0.433 & 13.763 & 2.372 \\
\hline Assets $_{\mathrm{t}-1}(\$ \mathrm{Bil})$ & 0.420 & 0.083 & 0.010 & 23.274 & 1.408 \\
\hline $\operatorname{Loss}_{\mathrm{t}-1}$ & 0.654 & 1 & 0 & 1 & 0.475 \\
\hline Neg. $\mathrm{OCF}_{\mathrm{t}-1}$ & 0.413 & 0 & 0 & 1 & 0.492 \\
\hline Filing Delay ${ }_{t}$ & 80.201 & 75 & 0 & 455 & 29.804 \\
\hline Big Four Auditor $_{\mathrm{t}-1}$ & 0.486 & 0 & 0 & 1 & 0.500 \\
\hline
\end{tabular}




\section{Mll Macrothink}

International Journal of Accounting and Financial Reporting

ISSN 2162-3082

2019, Vol. 9, No. 1

This table provides summary statistics of 788 firms included in our going concern analysis. The sample includes all companies which receive first-time going concern audit opinions and have financial and stock market data and daily short selling data available from 2005 to 2010 . See data appendix for variable definitions.

Table 2 presents the summary statistics of fundamental and market environment variables used in our analysis model. All continuous variables are winsorized at $1 \%$ and $99 \%$ levels to eliminate the impact of outliers. The first six rows present the measures of investor trading activities. Among the 788 selected financially distressed firms, 29.9\% received first-time going concern audit opinions. Row 2 and 3 indicate the excess short-term returns and momentum of the distressed firms are both negative before the $10 \mathrm{~K}$ releases. On average, stock returns are $-1.8 \%$ during the five-day pre-event window and $-6.8 \%$ during the six-month prior to the audit report release. The next row reports the abnormal short selling ratio, which measures the activity of a group of sophisticated investors. The mean abnormal shorting ratio increases by $26.1 \%$ during the pre-announcement five-day window. Other variables also show the sample selected include small to medium-sized companies with low market-to-book (mean $=2.12)$ and low trading prices $($ mean $=\$ 5.4)$.

Table 2 also reports statistics on the fundamental variables during the previous fiscal year-end. Consistent with research on financial distress, the average profitability in the full sample is low $(\mathrm{ROA}=-20.8 \%$ ) and the operating cash flow is averaged at $-1 \%$. Approximately $65.4 \%$ of firms report negative earnings and $41.3 \%$ of the firms show negative operating cash flows. Firms also present low corporate liquidity (mean $=2.416$ ). The average leverage used in the sample is $54.4 \%$. Also, about half of the sample $(48.6 \%)$ retain Big Four auditors. Finally, the average filing lag is 80.2 days from the fiscal year end to the submission of audit reports. The sample summary statistics show that our sample is comparable to DeFond et al. (2002).

\subsection{Descriptive Analysis by Opinion Types}

In this section, we report the univariate analysis results of the corporate fundamental and trading environment, partitioned by opinion types in auditor reports. Table 3 provides the comparison of variables selected in the analysis between companies receiving first-time going concern opinions (GC sample) and companies without going concern opinion (Non-GC sample).

We have matched our control sample based on a set of criterions defining financial distress. Besides the industry sectors, the two groups have several other features in common. We find that both going concern firms and the matched sample have similar sizes, mostly small to medium firms. The mean and median total assets of going concern firms are $\$ 429.8$ million and $\$ 35.9$ million, respectively, compared with $\$ 463.3$ million and $\$ 108.9$ million for the control sample, indicating that going concern firms are less valuable and more distressed.

Both groups have low stock trading prices close to or below $\$ 5$. Firms that receive a going concern opinion trade at an average of $\$ 2.30$ while the control firms are traded at an average of $\$ 6.1$. Both samples present low profitability. The mean ROA for going concern firms and 


\section{MInstitute ${ }_{\text {Intm }}^{\text {Macrothink }}$}

International Journal of Accounting and Financial Reporting

ISSN 2162-3082

2019, Vol. 9, No. 1

the matched sample are $-41.1 \%$ and $-12.2 \%$, indicating that firms in both samples experience loss. However, going concern firms have significantly severe lower profitability with $80.9 \%$ of firms in the loss position compared to $54.4 \%$ in the control sample. Going concern firms also have low operating cash flow. The mean is $-13.4 \%$ with $64.8 \%$ having negative operating cash flows. The control sample shows insufficient operating cash flows as well but in a less severe condition. The mean is $4 \%$ with $31.1 \%$ of firms having negative operating cash flows. Consistently, we find that the corporate liquidity of going concern firms are lower at $1.6 \%$ compared to $2.67 \%$ for the matched sample. Finally, the going concern companies have a high leverage ratio of $65 \%$, about $15 \%$ higher than the matched sample. Therefore, despite the sample selection criteria which provide us with a sample of financially distressed firms, the going concern firms show an even worse financial situation with low profitability, low or negative cash flows, and high debt-financed capital structure. We also report a comparison of accounting variables. Approximately $48.2 \%$ of going concern companies hire Big Four auditors, which is similar to the $46.5 \%$ retaining rate of the control sample. The average filing delay between audit report release date and the fiscal year-end is 91 days for going concern companies which is around the 90-day limit set by the SEC for the annual filing, compared to 77 days of the non-going concern sample.

Table 3. Two sample comparison of going concern and matched audit opinions

\begin{tabular}{|c|c|c|c|c|c|c|c|c|c|c|}
\hline & \multicolumn{3}{|c|}{ Going Concern sample } & \multicolumn{5}{|c|}{ Matched Sample } & \multirow[b]{2}{*}{ Diff. } & \multirow[b]{2}{*}{ T-value } \\
\hline & Mean & Median & Std & $\mathbf{N}$ & Mean & Median & Std & $\mathbf{N}$ & & \\
\hline $\operatorname{EXRET}(-5,-1)$ & -0.039 & -0.026 & 0.114 & 233 & -0.009 & -0.006 & 0.101 & 552 & -0.030 & $-5.32^{202}$ \\
\hline Momentum $_{(-150,-30)}$ & -0.222 & -0.235 & 0.374 & 233 & -0.052 & -0.086 & 0.376 & 552 & -0.17 & $-5.28^{* a t}$ \\
\hline Year-end Price (\$) & 2.303 & 1.080 & 3.968 & 233 & 6.193 & 3.650 & 7.654 & 552 & -3.89 & $-6.7^{* * * *}$ \\
\hline Abnormal Shorting $(-5,-1)$ & 0.662 & 0.081 & 1.803 & 214 & 0.316 & 0.077 & 1.178 & 499 & 0.347 & $2.34^{* * * *}$ \\
\hline Total Assets (\$Mil) & 429.005 & 45.792 & $1,876.33$ & 233 & 463.373 & 108.975 & $1,298.90$ & 552 & -34.37 & -0.27 \\
\hline$R O A$ & -0.411 & -0.414 & 0.289 & 233 & -0.122 & -0.065 & 0.168 & 552 & -0.289 & $-15.83^{* * *}$ \\
\hline Operating Cash Flow & -0.134 & -0.128 & 0.179 & 233 & 0.044 & 0.037 & 0.057 & 552 & -0.178 & $-18.74^{* * *}$ \\
\hline Leverage & 0.650 & 0.649 & 0.296 & 233 & 0.508 & 0.502 & 0.271 & 552 & $14 \%$ & $5.95^{* * *}$ \\
\hline Corporate Liquidity & 1.600 & 1.032 & 1.608 & 233 & 2.676 & 1.837 & 2.524 & 552 & -1.08 & $-5.52^{\ldots * *}$ \\
\hline $\operatorname{Loss}_{t-1}($ dummy $)$ & 0.809 & 1.000 & 0.394 & 233 & 0.544 & 1.000 & 0.499 & 552 & 0.26 & $6.61^{* t+t}$ \\
\hline Neg. $O C F_{t-1}($ dummy $)$ & 0.648 & 1.000 & 0.479 & 233 & 0.301 & 0.000 & 0.459 & 552 & 0.34 & $8.71^{* * *}$ \\
\hline Big Four Auditor (Dummy) & 0.482 & 0.000 & 0.501 & 233 & 0.465 & 0.000 & 0.499 & 552 & 0.017 & 0.4 \\
\hline Filing Delay & 91.588 & 88.000 & 39.843 & 233 & 77.100 & 75.000 & 27.088 & 552 & 14.5 & $5.34^{\text {*t* }}$ \\
\hline
\end{tabular}

This table provides a summary of financial variables of 788 audit opinions from 2005 to 2010 , including 233 public firms receiving first-time going concern audit opinion and 552 matched opinions from similar public firms without going concern statement. The control sample is constructed by matching a maximum of five clean but distressed firm-opinion with each first-time going concern opinion based on industry code, year, and the smallest differences between financial variables. *, **, *** represent significance at the $10 \%, 5 \%$, and $1 \%$ levels, respectively. See data appendix for variable definitions.

More important, we find some evidence that investors have predicted the upcoming going concern opinion from their trading patterns. Both pre-event short-term returns (mean $=-3.9 \%$ ) and six-month long-term momentum (mean $=-22.2 \%$ ) of going concern samples are significantly negative. On the other hand, the mean short-term and long-term returns of the control sample are at $-0.9 \%$ and $-5 \%$, respectively. It indicates that investors recognize and trade accordingly to the severity of the financial distress among both samples. 
The trading pattern of short sellers also confirms the value of going concern reports and how it is being targeted by sophisticated investors. Despite the average low trading price of going concern firms and the prior finding by D'Avolio (2002) that loan suppliers and sophisticated investors favor higher-priced stocks, short sellers increase their shorting volume significantly before the issues of going concern reports. The abnormal short selling increases by $66.2 \%$ days prior to the event, with a much higher amount than the average abnormal short selling (31.6\%) for the matched sample. Thus, we find that, even with lower stock prices, there is still a significant amount of short selling activities of going concern firms.

Table 4. Excess stock returns leading up to audit opinion release

\begin{tabular}{|c|c|c|c|c|c|c|c|c|}
\hline & \multicolumn{4}{|c|}{ Going Concern Sample } & \multicolumn{4}{|c|}{ Matched Sample } \\
\hline & Mean & Median & STD & Mean & Median & STD & Diff. & T-Value \\
\hline EXRET $[-30,-29]$ & $-1.49 \%$ *** & $-0.72 \%$ & 0.076 & $-0.48 \%^{*}$ & $-0.20 \%$ & 0.054 & $-1.01 \%^{*}$ & -1.91 \\
\hline EXRET $[-30,-28]$ & $-2.35 \%$ & $-2.25 \%$ & 0.081 & $-0.74 \%$ ** & $-0.37 \%$ & 0.067 & $-1.61 \%{ }^{* * *}$ & -2.64 \\
\hline EXRET $[-30,-27]$ & $-2.79 \%$ & $-2.55 \%$ & 0.094 & $-0.52 \%$ & $-0.36 \%$ & 0.071 & $-2.27 \%$ *** & -3.34 \\
\hline EXRET $[-30,-26]$ & $-2.60 \%{ }^{* * *}$ & $-2.70 \%$ & 0.104 & $-0.32 \%$ & $-0.53 \%$ & 0.082 & $-2.28 \% \%^{* * *}$ & -2.97 \\
\hline EXRET $[-30,-25]$ & $-3.16 \% \%^{* * *}$ & $-2.78 \%$ & 0.117 & $-0.27 \%$ & $-0.18 \%$ & 0.086 & $-2.89 \% \%^{* * *}$ & -3.47 \\
\hline EXRET $[-30,-24]$ & $-3.59 \%{ }^{* * *}$ & $-2.74 \%$ & 0.123 & $-0.66 \%$ & $-0.69 \%$ & 0.093 & $-2.94 \% \%^{* * *}$ & -3.31 \\
\hline EXRET $[-30,-23]$ & $-4.04 \% \%^{* * *}$ & $-3.36 \%$ & 0.134 & $-0.95 \%{ }^{*}$ & $-0.58 \%$ & 0.100 & $-3.09 \%$ **** & -3.22 \\
\hline EXRET $[-30,-22]$ & $-3.93 \% \%^{* * *}$ & $-3.46 \%$ & 0.140 & $-0.78 \%$ & $-0.61 \%$ & 0.108 & $-3.15 \%{ }^{* * *}$ & -3.08 \\
\hline EXRET $[-30,-21]$ & $-4.47 \%$ *** & $-4.34 \%$ & 0.153 & $-0.89 \%$ & $-0.31 \%$ & 0.116 & $-3.58 \% \%^{* * *}$ & -3.26 \\
\hline EXRET $[-30,-20]$ & $-5.13 \%{ }^{* * *}$ & $-5.43 \%$ & 0.171 & $-0.76 \%$ & $-0.80 \%$ & 0.119 & $-4.37 \%^{* * *}$ & -3.71 \\
\hline EXRET $[-30,-19]$ & $-4.97 \%$ *** & $-5.29 \%$ & 0.181 & $-0.58 \%$ & $-0.62 \%$ & 0.127 & $-4.39 \% \%^{* * *}$ & -3.51 \\
\hline EXRET $[-30,-18]$ & $-5.39 \%$ & $-5.78 \%$ & 0.184 & $-1.31 \%^{* *}$ & $-1.25 \%$ & 0.132 & $-4.08 \% \%^{* * *}$ & -3.17 \\
\hline EXRET $[-30,-17]$ & $-6.82 \%{ }^{* * *}$ & $-7.16 \%$ & 0.190 & $-1.38 \%{ }^{* *}$ & $-1.43 \%$ & 0.137 & $-5.43 \%^{* * *}$ & -4.07 \\
\hline EXRET $[-30,-16]$ & $-7.06 \%$ *** & $-6.76 \%$ & 0.189 & $-1.61 \%^{* *}$ & $-1.28 \%$ & 0.142 & $-5.46 \%{ }^{* * *}$ & -4.02 \\
\hline EXRET $[-30,-15]$ & $-7.39 \%$ & $-7.84 \%$ & 0.194 & $-1.72 \%^{* *}$ & $-1.33 \%$ & 0.146 & $-5.67 \%$ *** & -4.07 \\
\hline EXRET $[-30,-14]$ & $-7.84 \% \%^{* * *}$ & $-8.52 \%$ & 0.200 & $-1.80 \%^{* *}$ & $-1.06 \%$ & 0.151 & $-6.04 \%^{* * *}$ & -4.2 \\
\hline EXRET $[-30,-13]$ & $-9.31 \%{ }^{* * *}$ & $-10.30 \%$ & 0.205 & $-2.03 \%{ }^{* * *}$ & $-1.29 \%$ & 0.156 & $-7.27 \%^{* * *}$ & -4.91 \\
\hline EXRET $[-30,-12]$ & $-9.31 \% \%^{* * *}$ & $-9.52 \%$ & 0.201 & $-2.57 \% \%^{* * *}$ & $-1.47 \%$ & 0.160 & $-6.74 \% \%^{* * *}$ & -4.51 \\
\hline EXRET $[-30,-11]$ & $-9.20 \%{ }^{* * *}$ & $-10.50 \%$ & 0.204 & $-2.95 \%{ }^{* * *}$ & $-1.47 \%$ & 0.171 & $-6.25 \% \%^{* * *}$ & -4.01 \\
\hline EXRET $[-30,-10]$ & $-9.94 \%^{* * *}$ & $-9.58 \%$ & 0.212 & $-3.00 \%{ }^{* * *}$ & $-1.91 \%$ & 0.174 & $-6.94 \%{ }^{* * *}$ & -4.34 \\
\hline EXRET $[-30,-9]$ & $-10.37 \%^{* * *}$ & $-10.75 \%$ & 0.219 & $-3.09 \%$ & $-1.83 \%$ & 0.177 & $-7.28 \%^{* * *}$ & -4.44 \\
\hline EXRET $[-30,-8]$ & $-11.57 \%^{* * *}$ & $-11.68 \%$ & 0.224 & $-3.38 \% \%^{* * *}$ & $-1.72 \%$ & 0.183 & $-8.19 \%^{* * *}$ & -4.86 \\
\hline EXRET $[-30,-7]$ & $-11.78 \% \%^{* * *}$ & $-12.13 \%$ & 0.226 & $-3.49 \%$ *** & $-1.61 \%$ & 0.187 & $-8.29 \%$ *** & -4.84 \\
\hline EXRET $[-30,-6]$ & $-12.20 \%{ }^{* * *}$ & $-12.13 \%$ & 0.230 & $-4.12 \%{ }^{* * *}$ & $-1.81 \%$ & 0.193 & $-8.08 \% \%^{* * *}$ & -4.6 \\
\hline EXRET $[-30,-5]$ & $-12.87 \%^{* * *}$ & $-12.52 \%$ & 0.233 & $-3.91 \%{ }^{* *}$ & $-1.98 \%$ & 0.198 & $-8.96 \% \%^{* * *}$ & -4.98 \\
\hline EXRET [-30, -4] & $-13.37 \%^{* * *}$ & $-12.73 \%$ & 0.237 & $-4.28 \%{ }^{* *}$ & $-2.42 \%$ & 0.205 & $-9.09 \%^{* * *}$ & -4.93 \\
\hline EXRET $[-30,-3]$ & $-14.08 \%{ }^{* * *}$ & $-12.19 \%$ & 0.238 & $-4.18 \% * * *$ & $-2.33 \%$ & 0.209 & $-9.89 \%{ }^{* * *}$ & -5.28 \\
\hline EXRET $[-30,-2]$ & $-14.37 \%^{* * *}$ & $-13.16 \%$ & 0.240 & $-4.28 \%$ *** & $-2.02 \%$ & 0.211 & $-10.09 \%^{* * *}$ & -5.35 \\
\hline EXRET $[-30,-1]$ & $-14.55 \%{ }^{* * *}$ & $-14.11 \%$ & 0.242 & $-4.57 \%{ }^{* * *}$ & $-2.55 \%$ & 0.216 & $-9.98 \%^{* * *}$ & -5.19 \\
\hline
\end{tabular}

This table provides a summary of pre-announcement excess returns of the going concern and the control firms. The going concern group includes all companies which receive first-time 


\section{Ml Macrothink}

International Journal of Accounting and Financial Reporting

ISSN 2162-3082

2019, Vol. 9, No. 1

going concern audit opinions and have financial and stock market data and daily short selling data available from 2005 to 2010. The control group is constructed based on financial distress indicators during the same year and industry as the going concern firms. *, **, *** represent significance at the $10 \%, 5 \%$, and $1 \%$ levels, respectively. See data appendix for variable definitions.

Table 4 presents the comparison of cumulative excess returns during [-30, -1] days leading up to the audit report / going concern disclosure between the two samples. First, we find that both samples show negative stock returns prior to the audit report announcements, indicating negative market anticipation of financially distressed firms. Second, the table presents the monotonic decrease of going concern stock returns as the time gets closer to the audit report date. The cumulative returns are $-5.13 \%$ during $[-30,-20]$ days, $-9.94 \%$ during $[-30,-10]$ days, and a final $-14.55 \%$ during $[-30,-20]$ days. On the other hand, the cumulative excess returns to the comparable final distress firms (Non-GC firms) decrease less sharply. The returns are quite stable during $[-30,-20]$ days around $-1 \%$, and then gradually decrease to $-3 \%$ during the next ten trading days, and finally to $-4.57 \%$ during the last ten trading days. It shows investors' perception of the control firms is negative, but the decrease in the value of the control firms are significantly less severe than the going concern sample.

In summary, the descriptive statistics presented in Tables 3 and 4 are consistent with the hypothesis that market trading patterns conducted by investors are likely to identify firms receiving going concern audit reports. Both the variables measuring naive and sophisticated investors' behavior indicate their correct judgment.

\subsection{Multivariate Regression Results}

Although univariate tests provide some support for our hypotheses that market trading conditions predict the going concern reports, these results are non-conclusive because they do not control for other factors affecting the auditor's decision to issue a going concern opinion. In this section, we provide our multivariate regression models of the probability of recognizing a first-time going concern opinion using a financially distressed firm.

Table 5. Probit model of firm fundamental condition and going concern predictability

\begin{tabular}{|c|c|c|c|c|c|c|}
\hline \multirow[t]{3}{*}{ Dependent Variable } & \multicolumn{6}{|c|}{ Going Concern (1/0) } \\
\hline & (1) & & (2) & & (3) & \\
\hline & Coeff. & M. E. & Coeff. & M. E. & Coeff. & M. E. \\
\hline \multirow[t]{2}{*}{ EXRET $_{(-5,-1)}$} & & & $-2.582 * * *$ & -0.389 & $-3.093 * * *$ & -0.459 \\
\hline & & & $(0.992)$ & & $(1.049)$ & \\
\hline \multirow[t]{2}{*}{ Momentum $_{t}$} & & & $-1.283 * * *$ & -0.197 & $-1.221 * * *$ & -0.194 \\
\hline & & & $(0.313)$ & & $(0.328)$ & \\
\hline $\log \left(\right.$ Market Size $\left._{t}\right)$ & & & $-0.522 * * *$ & -0.839 & $-0.535 * * *$ & -0.090 \\
\hline
\end{tabular}




\begin{tabular}{|c|c|c|c|c|}
\hline & $(0.118)$ & & $(0.124)$ & \\
\hline \multirow[t]{2}{*}{$\mathrm{M} / \mathrm{B}_{\mathrm{t}}$} & -0.001 & 0.001 & 0.013 & 0.002 \\
\hline & $(0.031)$ & & $(0.033)$ & \\
\hline \multirow[t]{2}{*}{ Year-End Price $\mathrm{t}_{\mathrm{t}-1}$} & 0.012 & 0.002 & 0.012 & 0.001 \\
\hline & $(0.019)$ & & $(0.022)$ & \\
\hline
\end{tabular}

Abnormal Shorting

$(-5,-1)$

$0.191 * * \quad 0.038$

\begin{tabular}{|c|c|c|c|c|c|c|}
\hline & & & & & $(0.091)$ & \\
\hline \multirow[t]{2}{*}{ Total Assets $_{\mathrm{t}-1}$} & $0.159 * *$ & 0.026 & $0.282 * * *$ & 0.044 & 0.313 & 0.049 \\
\hline & $(0.067)$ & & $(0.088)$ & & $(0.092)$ & \\
\hline \multirow[t]{2}{*}{$\mathrm{ROA}_{\mathrm{t}-1}$} & $-4.701 * * *$ & -0.812 & $-4.529 * * *$ & -0.717 & $-4.466^{* * *}$ & -0.717 \\
\hline & $(0.445)$ & & $(0.489)$ & & $(0.050)$ & \\
\hline \multirow[t]{2}{*}{ Leverage $_{\mathrm{t}-1}$} & 0.699 & 0.151 & 0.457 & 0.107 & 0.189 & 0.073 \\
\hline & $(0.449)$ & & $(0.479)$ & & $(0.051)$ & \\
\hline \multirow[t]{2}{*}{ Liquidity $_{\mathrm{t}-1}$} & $-0.378 * * *$ & -0.051 & $-0.399 * * *$ & -0.052 & $-0.398 * * *$ & -0.052 \\
\hline & $(0.094)$ & & $(0.100)$ & & $(0.106)$ & \\
\hline \multirow[t]{2}{*}{ Loss $(1 / 0)_{\mathrm{t}-1}$} & 0.184 & 0.028 & 0.180 & 0.023 & 0.383 & 0.049 \\
\hline & $(0.244)$ & & $(0.262)$ & & $(0.278)$ & \\
\hline \multirow[t]{2}{*}{ Neg. OCF $(1 / 0)_{\mathrm{t}-1}$} & $1.020 * * *$ & 0.177 & $1.148 * * *$ & 0.182 & $1.192 * * *$ & 0.188 \\
\hline & $(0.226)$ & & $(0.240)$ & & $(0.254)$ & \\
\hline \multirow[t]{2}{*}{ Filing Delay ${ }_{t}$} & $0.016 * * *$ & 0.003 & $0.016 * * *$ & 0.002 & $0.016 * * *$ & 0.002 \\
\hline & $(0.003)$ & & $(0.003)$ & & $(0.003)$ & \\
\hline \multirow[t]{2}{*}{ Big Four Auditor $_{t}$} & -0.003 & -0.013 & 0.499 & 0.074 & $0.555^{*}$ & 0.088 \\
\hline & $(0.219)$ & & $(0.255)$ & & $(0.271)$ & \\
\hline $\mathrm{N}$ & 785 & & 785 & & 708 & \\
\hline Wald test & $189.6^{* * * *}$ & & $190.47 * * *$ & & $172.24 * * *$ & \\
\hline R-squared & $35.17 \%$ & & $39.94 \%$ & & $40.09 \%$ & \\
\hline
\end{tabular}

This table provides probit regression of the going concern opinion disclosure probability. The dependent variable is whether or not a firm receives the going concern audit opinion (0/1). The independent variables include both fundamental financials of the firm prior to the release as well as equity market signals, such as abnormal short selling, short-term excess returns, and momentum. T-statistics are reported in the parentheses. *, **, *** represent significance 
at the $10 \%, 5 \%$, and $1 \%$ levels, respectively. Marginal effects columns are provided beside the coefficients. See data appendix for variable definitions.

Table 5 presents three estimation results from probit regressions that measure the likelihood of receiving a going concern opinion. The dependent variable is the indicator of whether a firm receives a first-time going concern opinion. Model 1 presents a baseline case of our analysis including fundamental financial variables prior to the audit report similar to Defond et al. (2002). Model 2 introduces variables measuring stock market perceptions, and Model 3 further adds variables measuring the trading activity of sophisticated investors. The Marginal Effect (ME) columns in Table 5 provide some evidence on the economic significance of each of the coefficients. These statistics represent the change in the probability of a going concern opinion in response to a one-standard-deviation change in each of the respective independent variables, evaluated at the sample mean.

Model 1 does a reasonable job confirming that going concern decisions are somewhat predictable using fundamental financial and accounting variables with an R-squared of $40 \%$. Consistent with Defond et al. (2002), we find that total assets, profitability, corporate liquidity, negative cash flows, and filing delays are significantly related to the productiveness of going concern opinions. On the other hand, we do not find leverage, loss position, or the auditor identities have explanatory power of going concern issuances.

Model 2 and 3 introduce measures of trading patterns of both "naïve" and sophisticated investors. First, consistent with our univariate analysis, the probability of a going concern opinion is significantly related to low stock returns during the 5-day pre-event window. Specifically, the chance of receiving a going concern opinion increases by $45.9 \%$ in response to a one standard deviation decrease of short-term excess returns. Also, the negative momentum during the six months before the audit report is predictive of the future going concern opinion. The marginal effect is $-19.4 \%$. We also find that the probability of receiving a going concern is significantly related to low market value. Thus, both the short-term and long-term returns representing general investors' trading patterns show that the market significantly depresses the equity value of firms that have a high probability of receiving going concern opinions.

Most going concern and financially distressed companies are small in size and lower in stock price. Kausar et al. (2009) point out that the main clientele for such small firm stocks isare "naïve" or unsophisticated investors. However, in Model 3, we see that sophisticated investors also target these firms and their trading patterns are in line with the prediction of future going concern opinions. We show that short sellers, a group of investors who profit from negative corporate events, increase their abnormal short selling ratio significantly in firms with future going concern audit reports. The increased shorting is associated with a $3.8 \%$ increase in going concern probability, indicating the recognition of going concern recipients by short sellers. Moreover, controlling for the short selling activity, the results of both short-term and long-term stock returns remain unchanged. Overall, the probit analysis in Table 5 supports our hypothesis that going concern decisions are anticipated using signals contained in fundamental and market trading activities. 


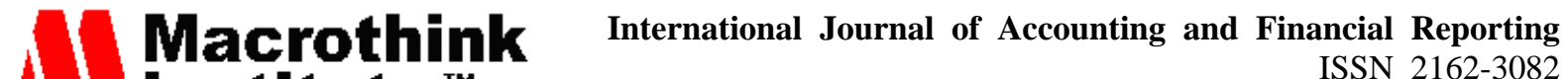 Institute ${ }^{T M}$

\section{Summary and Conclusion}

Using a sample of 233 non-finance firms with first-time going concern audit reports published between 2005 and 2010, we show that the market anticipates the issuance of a going concern audit report compared to a group of similar financially distressed firms. To be precise, we find that both the short-term excess returns immediately before the audit report is released and the six-month long-term excess return before the events of going concern firms are significantly lower than the control group. The results show that investors as a whole can identify firms with a high likelihood of receiving going concern reports.

We also demonstrate that the going concern audit report contains value-relevant information that attracts both "unsophisticated" and "sophisticated" investors. Besides the return measures that capture the trading activities of general investors, the abnormal short selling ratio is significantly positively related to the probability of going concern audit issuances. It not only provides the evidence of the anticipation of going concern issuances by different market participants (both sophisticated and unsophisticated), but it also contrasts prior research on the understanding of low-priced firms being less likely to be targeted by short sellers or sophisticated investors. The significantly high shorting volume prior to the going concern releases compared to the control firms indicates that short sellers have the ability to identify the upcoming negative corporate event and the information content is valuable enough to attract market pessimists to act upon it.

\section{References}

Al Haddidi, E., \& Abu Mousa, R. A. (2016). Using accounting and stock market price data to predict financial distress. Research Journal of Finance and Accounting, 7, 60-65.

Anderson, C. W., \& Huang, J. (2017). Institutional investment in IPO and post-IPO M\&A activity. Journal of Empirical Finance, 41, 1-18.

Anderson, C. W., Huang, J., \& Torna, G. (2017). Can investors anticipate post-IPO mergers and acquisitions?. Journal of Corporate Finance, 45, 496-521.

Behn, B. K., Choi, J.-H., \& Kang, T. (2008). Audit quality and properties of analyst earnings forecasts. The Accounting Review, 83(2), 327-349.

Blay, A. D., \& Geiger, M. A. (2001). Market expectations for first-time going-concern recipients. Journal of Accounting, Auditing and Finance, 16(3), 209-226.

Boehmer, E., Jones, C., \& Zhang, X. (2008). Which shorts are informed?. Journal of Finance, 63, 491-527.

Boehmer, E., \& Wu, J. (2013). Short selling and the price discovery process. The Review of Financial Studies, 26(2), 287-322.

Carcello, J. V., Hermanson, D. R., \& Huss, H. F. (1995). Temporal changes in bankruptcy-related reporting. Auditing: A Journal of Practice \& Theory, 14(2), 133-143. 


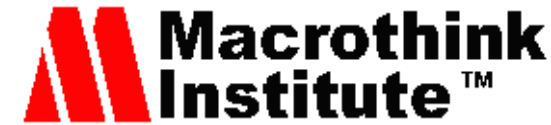

International Journal of Accounting and Financial Reporting

ISSN 2162-3082

Carlson, S., Glezen, G., \& Benefield, M. (1998). An investigation of investor reaction to the information content of a going concern audit report while controlling for concurrent financial statement disclosures. Quarterly Journal of Finance and Accounting, 37(3), 25-39.

Chen, K. C. W., \& Church, B. (1996). Going concern opinions and the market's reaction to bankruptcy filings. The Accounting Review, 71(1), 117-128.

Cheung, A. W. K., Kot, H. W., Lam, E. F. Y., \& Leung, H. K. M. (2018). Toward understanding short - selling activity: demand and supply. Accounting and Finance.

Chow, C., \& Rice, S. (1982). Modified audit opinions and auditor switching. The Accounting Review, 57, 326-335.

Christophe, S., Ferri, M., \& Angel, J. (2004). Short-selling prior to earnings announcements. Journal of Finance, 59, 1845-1875.

Christophe, S., Ferri, M., \& Hsieh, J. (2010). Informed trading before analyst downgrades: Evidence from short sellers. Journal of Financial Economics, 95, 85-106.

D'Avolio, G. (2002). The market for borrowing stock. Journal of Financial Economics, 66(2-3), 271-306.

DeAngelo, L. (1981). Auditor size and audit quality. Journal of Accounting and Economics, 3, 183-199.

DeFond, M. L., Raghunandan, K., \& Subramanyam, K. R. (2002). Do non-audit service fees impair auditor independence? Evidence from going-concern audit opinions. Journal of Accounting Research, 40, 1247-1274.

Desai, H., Krishnamurthy, S., \& Venkataraman, K. (2006). Do short sellers target firms with poor earnings quality? Evidence from earnings restatements. Review of Accounting Studies, 11(1), 71-90.

Dodd, P., Dopuch, N., Holthausen, R., \& Leftwich, R. (1984). Qualified audit opinions and stock prices. Journal of Accounting and Economics, 6, 3-38.

Dongcheol, K., Lee, I., \& Na, H. J. (2019). Financial distress, short sale constraints, and mispricing. Pacific-Basin Finance Journal, 53, 94-111.

Drake, M. S., Myers, L. A., Scholz, S., \& Sharp, N. Y. (2015). Short selling around accounting restatements: When do bears pounce?. Journal of Accounting, Auditing, and Finance, 30(2), 218-245.

Efendi, J., \& Swanson, E. P. (2009). Short seller trading in companies with a severe accounting irregularity.

Elliott, J. (1982). Subject to audit opinions and abnormal security returns: outcomes and ambiguities. Journal of Accounting Research, 20(2), 617-38.

Engelberg, J. E., Reed, A. V., \& Ringgenberg, M. C. (2012). How are shorts informed? Short sellers, news, and information processing. Journal of Financial Economics, 105(2), 260-278. 


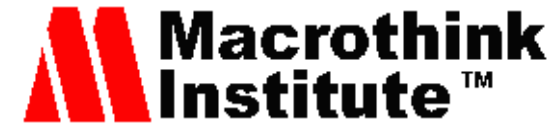

International Journal of Accounting and Financial Reporting

ISSN 2162-3082 2019, Vol. 9, No. 1

Fang, V. W., Huang, A. H., \& Karpoff, J. M. (2016). Short Selling and Earnings Management: A Controlled Experiment. The Journal of Finance, 71, 1251-1294.

Field, L. C., \& Lowry, M. (2009). Institutional versus individual investment in IPOs: The importance of firm fundamentals. Journal of Financial and Quantitative Analysis, 44(3), 489-516.

Firth, M. (1978). Qualified audit reports: Their impact on investment decisions. The Accounting Review, 642-650.

Fleak, S. K., \& Wilson, E. R. (1994). The Incremental Information Content of the Going-Concern Audit Opinion. Journal of Accounting, Auditing and Finance, 9(1), 149-166.

Geiger, M., Raghunandan, K., \& Rama, D. V. (1998). Costs associated with going-concern modified audit opinions: An analysis of auditor changes, subsequent opinions, and client failures. Advances in Accounting, 16, 117-139.

Griffin, P. A. (2003). A league of their own? Financial analysts' responses to restatements and corrective disclosures. Journal of Accounting, Auditing \& Finance, 18(4), 479-517.

Herbohn, K., Ragunathan, V., \& Garsden, R. (2007). The horse has bolted: Revisiting the market reaction to going concern modifications of audit reports. Accounting and Finance, 47, 473-493.

Holder-Webb, L. M., \& Wilkins, M. S. (2000). The incremental information content of SAS No. 59 going-concern opinions. Journal of Accounting Research, 38(1), 209-219.

Hopwood, W., McKeown, J. C., \& Mutchler, J. F. (1989). A test of the incremental explanatory power of opinions qualified for consistency and uncertainty. The Accounting Review, 64(1), 28-48.

Huang, J., Yu, H., \& Zhang, Z. (2019). Short selling prior to going concern disclosures. Working Paper.

Jiang, L., \& Pang, L. (2016). Does short selling enhance the Allocational allocational role of stock price? Evidence from Hong Kong. Journal of International Financial Management \& Accounting, 27, 269-297.

John, T. A. (1993). Accounting measures of corporate liquidity, leverage, and costs of financial distress. Financial Management, 22(3), 91-100.

Johnson, E., Khurana, I., K., \& Reynolds, J. K. (2010). Audit-firm tenure and the quality of financial reports. Contemporary Accounting Research, 19(4), 637-660.

Jones, F. (1996). The information content of the auditor's going concern evaluation. Journal of Accounting and Public Policy, 15, 1-27.

Karpoff, J. M., \& Lou, X. (2010). Short sellers and financial misconduct. Journal of Finance, 65, 1879-1913.

Kausar, A., Taffler, R., \& Tan, C. (2009). The going-concern market anomaly. Journal of Accounting Research, 47, 213-239.

Kim, C., Mauer, D., \& Sherman, A. (1998). The determinants of corporate liquidity: theory and evidence. Journal of Financial and Quantitative Analysis, 33(3), 335-359. 


\section{MlMacrothink}

International Journal of Accounting and Financial Reporting ISSN 2162-3082

Massa, M., Zhang, B. H., Zhang, H. (2015). The Invisible Hand of Short Selling: Does Short Selling Discipline Earnings Management?. The Review of Financial Studies, 28(6), 1701-1736.

Meng, Q. B., Li, Y., Jiang, X. Y., \& Chan, K. C. (2017). Informed or speculative trading? Evidence from short selling before star and non-star analysts' downgrade announcements in an emerging market. Journal of Empirical Finance, 42, 240-255.

Menon, K., \& Williams, D. (2010). Investor reaction to going concern audit reports. The Accounting Review, 85, 2075-2105.

Mutchler, J. (1985). A multivariate analysis of the auditor's going-concern opinion decision. Journal of Accounting Research, 23(2), 668-682.

Mutchler, J. F. (1984). Auditors' perceptions of the going-concern opinion decision. Auditing: A Journal of Practice \& Theory, 3, Spring, 17-30.

Mutchler, J., Hopwood, W., \& McKeown, J. (1997). The influence of contrary information and mitigating factors on audit opinion decisions on bankrupt companies. Journal of Accounting Research, 35(2), 295-310.

Raghunandan, K., \& Rama, D. V. (1995). Audit reports for companies in financial distress: before and after SAS No. 59. Auditing: A Journal of Practice \& Theory, 14(1).

Reynolds, J. K., \& Francis, J. R. (2000). Does size matter? The influence of large clients on office-level auditor reporting decisions. Journal of Accounting and Economics, 30(3), 375-400.

Taffler, R. J., Lu, J., \& Kausar, A. (2004, December). In denial? Stock market under-reaction to going-concern audit report disclosures. Journal of Accounting and Economics, 38, 263-296.

\section{Note}

Note 1 . Going concern opinions submitted other than $10-\mathrm{K}$ reports represent only a small portion of the initial sample screening. Since we require comparable accounting announcements of the matched sample and the treatment sample, we only include going concern opinions reported in the $10-\mathrm{K}$ and exclude opinions shown in other reports in our final sample.

\section{Copyright Disclaimer}

Copyright for this article is retained by the author(s), with first publication rights granted to the journal.

This is an open-access article distributed under the terms and conditions of the Creative Commons Attribution license (http://creativecommons.org/licenses/by/4.0/) 